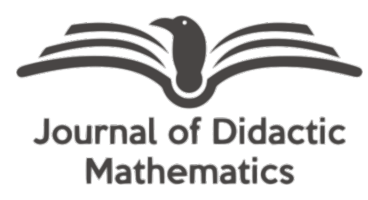

\title{
Desain soal-soal kemampuan literasi matematis untuk siswa SMP
}

\section{Listri Maya Sari*}

Universitas Muhammadiyah Bengkulu, Bengkulu, Indonesia, 38113

\section{Adi Asmara}

Universitas Muhammadiyah Bengkulu, Bengkulu, Indonesia, 38113

*Corresponding Author: listrimayasari@gmail.com

\begin{abstract}
This research aimed to produce questions of mathematical literacy ability of Mathematical literacy ability on Triangular material for Class VII Junior High School students that are valid and practical and have a good level of difficulty and discriminatory index. This research used the Tessmer development model. Tessmer's development stages include preliminary, self-evaluation, expert review, one-to-one, and small group. The test subjects of this study were class VII students of SMP Negeri 02 Kepahiang, totaling 30 students. The selection of test subjects includes high, medium and low abilities. The data analysis technique of this study used qualitative analysis at the expert review and one to one stage and quantitative analysis at the small group stage by analyzing items based on the level of difficulty and discriminating power index. The results of the research show that the 10 questions developed, 10 questions with indicators of mathematical literacy ability on triangular material are valid and practical, 7 questions are said to be good based on the level of difficulty and discriminatory index, so that they can be used by all students of SMPN 02 Kepahiang.
\end{abstract}

Historis Artikel:

Diterima: 9 November 2021

Direvisi: 12 Desember 2021

Disetujui: 27 Desember 2021

\section{Keywords:}

mathematical

literacy; triangle; valid; practical

Sitasi: Sari, L. M., \& Asmara, A. (2021). Desain soal-soal kemampuan literasi matematis untuk siswa SMP. Journal of Didactic Mathematics, 2(3), 111-121. Doi: 10.34007/jdm.v2i3.1002

\section{PENDAHULUAN}

Seiring dengan perkembangan zaman di era globalisasi ini pendidikan menjadi salah satu aspek utama dalam pembangunan dan meningkatkan kualitas Sumber Daya Manusia (SDM). Rendahnya mutu SDM bangsa Indonesia saat ini adalah akibat rendahnya mutu pendidikan, khususnya matematika (Masjaya \& Wardono, 2018). Seiring dengan itu kualitas pendidikan di Indonesia harus dilakukan perubahan yang lebih baik. Pendidikan yang dapat membekali siswanya dengan keterampilan-keterampilan yang dibutuhkan pada abad ini merupakan pendidikan yang berkualitas (Nahdi, 2019). Semakin baik sistem pendidikan yang ada di suatu negara, maka semakin berkualitas sumber daya manusia yang diciptakan (Sasongko dkk., 2016). Sistem pendidikan yang diterapkan akan berkualitas baik apabila proses dan hasil pendidikan semakin baik.

Sistem pendidikan yang diterapkan di Indonesia jika mengacu pada beberapa hasil studi belum sesuai dengan hasil yang diharapkan. Perubahan ke arah yang lebih baik harus dilakukan karena kualitas pendidikan di Indonesia saat ini menurun (Anwar, 2018). Artinya hal ini menunjukkan bahwa diperlukannya cara untuk meningkatkan kualitas SDM agar sesuai dengan hasil yang diharapkan. Peningkatan SDM dapat dilakukan melalui pembelajaran di sekolah dengan berbagai mata pelajaran, salah satunya yaitu matematika. Matematika merupakan salah satu mata pelajaran yang diajarkan pada semua jenjang pendidikan, dari Sekolah Dasar hingga perguruan tinggi. Matematika merupakan ilmu universal yang mendasari perkembangan teknologi modern, mempunyai peran penting dalam berbagai disiplin ilmu dan memajukan daya pikir manusia, serta berperan penting dalam membekali siswa agar dapat berfungsi secara efektif di era modern (Susanti \& Maharani, 2016). Pembelajaran matematika di sekolah idealnya harus dapat 
membekali siswa dengan kemampuan dan keterampilan untuk menghadapi permasalahan dalam kehidupan sehari-hari (Ramadianti dkk., 2018). Dengan demikian matematika dapat diartikan memegang peranan penting dalam bidang pendidikan, karena matematika digunakan sebagai sarana berpikir untuk mengembangkan keterampilan penalaran, berpikir kritis, logis, sistematis dan membantu memecahkan masalah sehari-hari.

Matematika menjadi salah satu mata pelajaran yang ditakuti oleh sebagian besar siswa. Hal ini diindikasikan dari sebagian besar siswa menguasai matematika dengan cara menghapal tidak dengan pemahaman, sehingga ketika diberikan soal dengan konteks berbeda siswa mengalami kesulitan dalam menyelesaikannya (Asmara \& Risnanosanti, 2019). Oleh karena itu diperlukan cara untuk membuat matematika menjadi menarik, salah satunya dengan mengaitkan pembelajaran matematika ke dalam kehidupan sehari-hari. Misalnya, siswa menghadapi masalah dunia nyata yang berkaitan dengan penerapan matematika. Untuk memahami masalah-masalah yang berkaitan dengan matematika tentunya siswa terlebih dahulu harus menguasai dan memahami konsep-konsep matematika. Kemampuan menjelaskan masalah yang berkaitan dengan matematika disebut literasi matematis.

Literasi matematis diartikan sebagai kemampuan siswa untuk merumuskan, menggunakan, dan menafsirkan matematika dalam berbagai konteks. Ini termasuk penalaran matematis dan menggunakan konsep, prosedur, fakta dan alat matematika untuk menggambarkan, menjelaskan dan memprediksi fenomena/kejadian (OECD, 2019). Seseorang yang memiliki literasi matematika akan menyadari atau memahami konsep matematika mana yang relevan dengan masalah yang dihadapinya (Sari, 2015). Dalam matematika ada banyak konsep terutama yang dipelajari oleh siswa SMP, diantara sekian banyak konsep yang dipelajari yaitu konsep segitiga. Segitiga merupakan pokok bahasan pada materi bangun datar. Sumiati \& Agustini (2020) berpendapat bahwa penguasaan dan pemahaman konsep-konsep bangun datar segitiga dengan baik sangat penting untuk siswa agar siswa tidak mengalami kesulitan dalam mengaplikasikan materi bangun datar dalam bidang matematika maupun dalam kehidupan sehari-hari. Selain itu juga bangun datar merupakan materi prasyarat dalam mempelajari dan memahami materi bangun ruang. Artinya pemahaman siswa terhadap segitiga akan membawa dampak ketika siswa memahami bangun ruang. Sehingga perlu penajaman dan perlu kemampuan literasi yang cukup terhadap segitiga.

Peningkatan kemampuan literasi matematis dapat dilakukan dengan membiasakan siswa dalam mengerjakan soal yang dapat melatih kemampuan literasi matematis. Wibowo dkk. (2019) mengatakan bahwa berkaitan dengan pengukuran kemampuan literasi matematis, soal-soal yang digunakan guru pada proses evaluasi hasil belajar siswa belum sesuai dengan indikator pada setiap level literasi matematis, karena soal yang diberikan tersebut hanya menguji pengetahuan prosedural siswa dalam menggunakan rumus matematika dan belum mampu mengasah kemampuan berpikir matematika siswa. Artinya, siswa Indonesia masih kurang terlatih menyelesaikan soal yang dapat meningkatkan kemampuan literasi matematis. Siswa terbiasa mengerjakan soal-soal yang sama dengan contoh yang diberikan oleh guru. Hal ini mengakibatkan siswa mengalami kesulitan ketika diberikan soal yang berbeda dengan yang diajarkan dalam proses pembelajaran.

Hal ini menunjukkan bahwa diperlukan pengembangan soal-soal berbasis kemampuan literasi matematis yang valid dan praktis serta memiliki tingkat kesukaran dan indeks daya pembeda yang baik sebagai referensi soal-soal berbasis kemampuan literasi matematis. Oleh karena hal itu yang mendukung untuk melakukan penelitian tentang "Kemampuan Literasi Matematis Untuk Siswa SMP". Hasil pengembangan soal diharapkan dapat melatih kemampuan literasi matematis siswa pada materi segitiga dalam pembelajaran matematika.

\section{METODE}

Penelitian ini adalah penelitian pengembangan atau Reseach and Development. Metode penelitian ini menggunakan model pengembangan Tessmer 1993 yang diadopsi oleh Zulkardi (2006) Tahapan model pengembangan ini meliputi tahap preliminary, self evaluation, expert review, Oneto-one, dan small group. 
Desain soal-soal kemampuan literasi...

Pada tahap preliminary, peneliti melakukan analisis kurikulum terkait materi di kelas VII sesuai dengan kurikulum 2013, analisis materi segitiga dan analisis siswa. Selanjutnya peneliti mendesain soal-soal sesuai dengan materi dan indikator kemapuan literasi matematis yang akan dikembangkan.

Proses selanjutnya peneliti melakukan tahap self evaluation terhadap soal-soal yang telah dikembangkan. Hasil dari tahap self evaluation ini disebut prototype I. Selanjutnya pada tahap expert review, berdasarkan self evaluation hasil dari prototype I yang telah di desain diberikan kepada validator untuk divalidasi. Validator diminta memvalidasi secara kualitatif berdasarkan konten, konstruk, dan bahasa dari soal-soal yang dikembangkan. Komentar/saran dari validator digunakan sebagai bahan untuk merevisi prototype I. Hasil revisi protoype I yang telah valid disebut prototype II.

Tahap selanjutnya yaitu tahap one-to-one. Pada tahap ini peneliti meminta kepada 3 orang siswa yang berkemampuan tinggi, sedang dan rendah untuk memberikan saran dan komentar terhadap soal yang diberikan oleh peneliti. Uji one-to one digunakan untuk uji "keterbacaan" soal. Hasil saran dan komentar yang diberikan siswa digunakan untuk pertimbangan keterbacaan soal yang telah dibuat.

Tahap selanjutnya yaitu small group, prototype II yang sudah valid diuji cobakan ke 30 orang siswa SMP yang terdiri dari siswa berkemampuan tinggi, sedang dan rendah. Dalam penelitian ini diminta 30 orang siswa SMP mengerjakan soal yang telah dibuat untuk menentukan tingkat kesukaran dan indeks daya pembeda butir soal. Instrumen pengumpulan data, yaitu dokumen, lembar validasi, Lembar komentar/saran, prototype. Teknik analisis data yang digunakan pada penelitian ini adalah analisis kualitatif dan kuantitatif. Pada tahap expert review komentar dan saran dari pakar dianalisis secara deskriptif kualitatif dan digunakan sebagai bahan untuk merevisi prototype. Revisi ini berupa komentar dan saran dari pakar terhadap kalimat-kalimat yang belum tepat agar dapat dilakukan perbaikan. Revisi pada prototype dilakukan hingga memperoleh prototype yang valid. Hasil revisi dari expert review dan one-to-one terhadap prototype I kemudian disebut prototype II. Hasil komentar dari siswa pada tahap one-to-one dianalisis secara kualitatif sebagai pertimbangan keterbacaan soal yang telah dibuat. Tahap small group dilakukan analisis secara kuantitatif dengan diperolehnya data empirik berupa skor. Skor tersebut akan digunakan untuk mengetahui karakteristik soal yaitu: Tingkat Kesukaran Butir Soal dan Daya Pembeda Butir Soal.

Indeks kesukaran butir soal dapat diperoleh dengan menggunakan rumus (Allen \& Yen, 1979):

$$
p i=\frac{\text { Jumah skor yang diperoleh test } i}{\text { (nilai maksimum butir }) \times(\text { jumlah seluruh test })}
$$

Angka indeks daya pembeda soal dapat diperoleh dengan menggunakan rumus (Allen \& Yen, 1979):

Keterangan:

$$
d i=\frac{U i}{n i U}-\frac{L i}{n i L}
$$

$\mathrm{Ui}=$ Jumlah skor kelompok atas

$\mathrm{Li}=$ Jumlah skor kelompok bawah

niU $=$ (Banyak testi kelompok atas) $\mathrm{x}$ (Skor maksimum butir-i)

niL $=($ Banyak testi kelompok bawah) $\mathrm{x}$ (Skor maksimum butir-i)

\section{HASIL DAN PEMBAHASAN}

Ada lima tahapan yang dilakukan pada penelitian ini, yaitu:

Preliminary

Tahap Persiapan

Pada tahap ini, ditentukan tempat yang dijadikan tempat penelitian yaitu SMPN 02 Kepahiang. Selanjutnya mengatur jadwal penelitian dan prosedur kerja sama dengan guru mata pelajaran matematika. 
Analisis Kurikulum

Kurikulum yang digunakan di SMPN 02 Kepahiang adalah Kurikulum 2013. Dalam Rencana Proses Pembelajaran (RPP) salah satunya dirancang untuk mengembangkan kemampuan literasi. Dari kegiatan ini diperoleh Kompetensi Inti (KI), KompetensI Dasar (KD), dan Silabus yang akan digunakan untuk mengembangkan soal matematika dengan kemampuan literasi matematis.

Analisis Materi

Pada tahap ini yang dilakukan adalah mengidentifikasi materi pembelajaran matematika SMP, meliputi aspek-aspek sebagai berikut: Materi pembelajaran matematika kelas VII, meliputi; bilangan bulat dan pecahan, himpunan, bentuk aljabar, persamaan dan pertidaksamaan linear satu variabel, perbandingan, aritmatika social, garis dan sudut, bangun datar (segiempat dan segitiga) dan penyajian data. Pada penelitian ini materi yang digunakan yaitu materi segitiga. Materi segitiga merupakan materi prasyarat yang harus dipelajari siswa untuk menuju pembelajaran ke materi bangun ruang, sehingga perlu pemahaman yang cukup agar materi selanjutnya dapat dipahami dengan mudah. Adapun materi dan soal yang dipelajari siswa SMPN 02 Kepahiang pada materi segitiga seperti terlihat pada Gambar 1 dan Gambar 2.

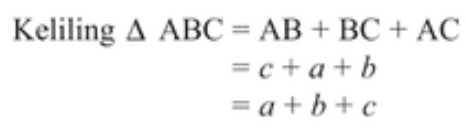

Jadi, keliling $\triangle \mathrm{ABC}$ adalah $a+b+c$.

Dari uraian di atas dapat disimpulkan sebagai berikut. adalah Suatu segitiga dengan panjang sisi $a, b$, dan $c$, kelilingnya

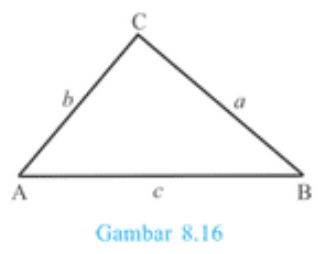

$$
K=a+b+c .
$$

Gambar 1. Materi keliling segitiga

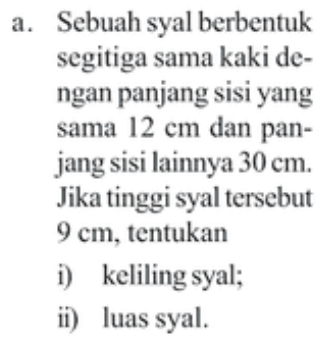

Gambar 2. Contoh soal segitiga

Analisis Siswa

Pada analisis ini diketahui latar belakang pengetahuan siswa dimana siswa tersebut memiliki kemampuan yang heterogen. Pada analisis siswa juga diketahui bahwa siswa sudah pernah mempelajari materi segitiga.

\section{Self Evaluation}

Pada tahap ini, diperoleh prototype I sebanyak 10 soal beserta jawabannya yang telah di desain melalui tahap penilaian dan diperbaiki sendiri berdasarkan konten, konstruk, dan bahasa sebelum diberikan kepada validator pada tahap expert review untuk proses validasi. 
Tabel 1. Prototype I

\section{No}

1

Aku adalah benda 3 dimensi yang memiliki sisi datar

Aku memiliki tiga sisi yang berhubungan dan memenuhi teorema phytagoras

Aku juga memiliki sebuah sudut siku $\left(90^{\circ}\right)$

Siapakah aku?

2 Faris mempunyai kawat sepanjang $98 \mathrm{~cm}$. Kawat tersebut seluruhnya akan ia gunakan untuk membuat segitiga sama kaki dengan panjang alas $40 \mathrm{~cm}$. Tentukan panjang sisi miring, tinggi segitiga, serta luas segitiga yang dibuat oleh Faris.

3 Di akhir pembelajaran mata pelajaran matematika Ibu Maya memberikan kuis kepada siswa kelas VII. Kuis tersebut berkaitan dengan materi yang baru saja dipelajari pada hari itu yaitu materi segitiga. Ibu Maya menjelaskan sifat-sifat segitiga berdasarkan macam segitiganya.

Segitiga yang pertama memiliki ciri-ciri sebagai berikut:

- Mempunyai dua sisi yang sama panjang

- Mempunyai dua sudut yang sama besar

Segitiga yang kedua memiliki ciri-ciri sebagai berikut:

- Ketiga sisinya sama panjang

- Ketiga sudutnya berukuran $60^{\circ}$

Segitiga yang ketiga memiliki ciri-ciri sebagai berikut:

- Ketiga sisinya mempunyai ukuran yang berbeda

- Ketiga sudutnya mempunyai ukuran yang berbeda

Kemudian ibu Maya menyuruh siswa nya menyebutkan nama segitiga sesuai dengan ciri-ciri yang telah disebutkan dan menjelaskan alasan menyebutkan nama segitiga tersebut. Bantulah siswa ibu Maya dan menjelaskan alasannya.

4 Risol merupakan makanan yang banyak diminati banyak orang, mulai dari kalangan menengah ke bawah maupun dari kalangan menengah ke atas. Makanan ini memiliki berbagai varians isi dan bentuk yang berbeda-beda.

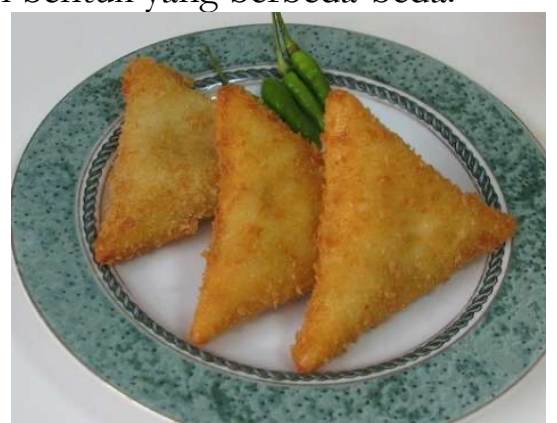

Bu Rita merupakan penjual risol, pada hari minggu bu Rita mendapat pesanan $2 \mathrm{~kg}$ risol. Pelanggan bu Rita menginginkan risol yang berbentuk segitiga dan isi risol tersebut berupa irisan wortel, kentang dan daun bawang. Jika salah satu risol yang dibuat oleh bu Rita alasnya sepanjang jari telunjuk atau setara dengan $5 \mathrm{~cm}$ dan sisi-sisi nya lainnya memiliki Panjang yang sama. Maka tentukan panjang dari kulit lumpia tersebut!

\section{Self-Evaluation}

Menambahkan kata

"sebuah" sebelum kata

"benda" menjadi "Aku

adalah sebuah benda ..."

Tidak ada yang

diperbaiki

Tidak ada yang

diperbaiki

Tidak ada yang

diperbaiki 
5 Di desa Sinar Gunung akan dibangun sebuah gapura dengan bagian atas gapura atas tersebut berbentuk segitiga sama kaki dengan panjang alas $4,5 \mathrm{~m}$ dan tinggi $2 \mathrm{~m}$. Bagian berbentuk segitiga pada sisi depan tersebut akan dicat berwarna merah. Sebelum dicat diberi sebuah lubang yang berbentuk segitiga dengan luas $10.000 \mathrm{~cm}^{2}$. Cat kaleng yang berisi 1 liter cat dapat mengecat seluas $7000 \mathrm{~cm}^{2}$. Warga harus menyediakan biaya untuk membeli cat yang berisi 1 liter/kaleng dengan harga satu kaleng cat Rp. 60.000

a) Berapakah banyak cat minimal dalam satuan kaleng yang dibutuhkan warga untuk mengecat bagian tersebut? Berikan penjelasannya!

b) Tentukan biaya yang harus disediakan warga untuk membeli cat tersebut! Berikan penjelasannya!

6 Kapal "Maritim" berlayar ke arah utara sejauh $55 \mathrm{~km}$ dari pelabuhan A menuju pelabuhan $\mathrm{B}$, kemudian dilanjutkan ke arah timur menuju pelabuhan $C$ sejauh $48 \mathrm{~km}$. Saat kembali ke pelabuhan A kapal tersebut tidak melalui pelabuhan B, sehingga dari pelabuhan $C$ langsung menuju pelabuhan $A$. Sebuah kapal lain, yaitu kapal "Bahari" berangkat dari pelabuhan D ke arah selatan menuju pelabuhan C sejauh 53 km. Kapal "Bahari" menyusul kapal "Maritim" menuju pelabuhan A dengan lintasan yang sama. Selanjutnya kapal "Bahari" kembali ke pelabuhan D tanpa melalui pelabuhan C sejauh $98 \mathrm{~km}$. Tentukan selisih jarak yang ditempuh antara kapal "Maritim" dan kapal "Bahari”!

7 Pak Deni akan membuat sebuah taman bunga berbentuk segitiga siku-siku dengan ukuran pada sisi siku-sikunya adalah 5 meter dan 12 meter. Pada pinggiran taman akan diletakkan batu-batu. Tentukan:

a. Panjang batu-batu yang diletakkan di pinggiran taman

b. Luas lahan untuk taman tersebut

c. Biaya untuk pembuatan taman jika pembuatan taman diperkirakan Rp 300.000,00 per $\mathrm{m}^{2}$

8 Gambar di bawah ini merupakan gambar bangun datar yang merupakan segitiga siku-siku dan yang bukan segitiga sikusiku. Dari gambar tersebut dapatkah kamu menunjukkan gambar mana yang merupakan segitiga siku-siku dan berikan alasanmu!

Serta berikan alasan mengapa gambar yang lainnya bukan merupakan gambar segitiga siku-siku!

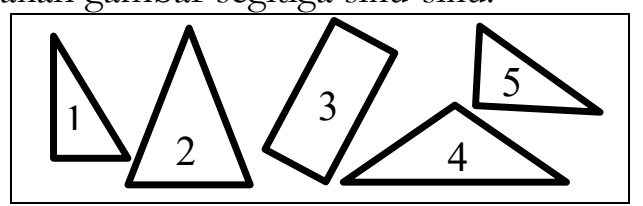

$9 \quad$ Pak Beruan mempunyai kebun jagung seluas $84 \mathrm{~m}^{2}$ yang berbentuk segitiga dengan panjang sisi-sisinya $24, x$, dan $(3 x+4)$ dalam satuan meter, seperti pada gambar dibawah ini
Menghilangkan kata "atas" setelah kalimat "bagian atas gapura"

Tidak ada yang diperbaiki

Tidak ada yang diperbaiki

Tidak ada yang diperbaiki

Tidak ada yang diperbaiki 


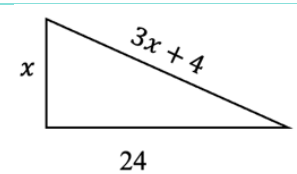

Jika pak Beruan ingin memagari kebun jagung tersebut dengan pagar bambu. Dapatkah kalian membantu pak Beruan menentukan panjang pagar bambu yang mengelilingi kebun jagung tersebut?

10 Diberikan beberapa batang korek api yang akan digunakan untuk membentuk segitiga sama sisi. Susunan batang korek api membentuk segitiga sama sisi tidak melebihi 2(dua) tingkat.Banyak batang korek api yang disediakan dan banyak maksimum segitiga dengan panjang sisi satu satuan korek api disajikan pada tabel berikut.

Menambahkan unsur $\mathrm{n}$ pada baris pertama kolom pertama dan $\mathrm{s}$ pada baris kedua kolom kedua pada tabel Tabel 1

\begin{tabular}{|c|c|c|c|c|c|c|c|c|c|c|}
\hline & 3 & 5 & 7 & 9 & 11 & 13 & 15 & 17 & 19 & \\
\hline & 1 & 2 & 3 & 4 & 5 & 6 & 7 & 8 & 9 & $\ldots . .$. \\
\hline
\end{tabular}

Keterangan:

n: banyak batang korek api

s: banyak segitiga yang dibentuk

Sajikan data pada tabel dalam gambar segitiga sama sisi.

\section{Expert Review}

Pada tahap ini soal-soal kemampuan literasi matematis level 3 yang telah didesain ke dalam kartu soal yang berisi kisi-kisi soal, indikator kemampuan literasi matematis akan diberikan kepada 2 orang dosen pendidikan matematika Universitas Muhammadiyah Bengkulu dan 1 orang guru matematika SMPN 02 Kepahiang untuk divalidasi berdasarkan focus prototype yaitu konten, konstruk, dan bahasa. Proses validasi dilakukan sebanyak 4 kali, yaitu soal-soal harus direvisi berdasarkan komentar/saran dari validator. Pada tahap validasi keempat prototype I telah dinyatakan valid oleh ketiga validator. Hasil dari tahapan ini ialah didapatkan 10 soal kemampuan literasi matematis yang valid berdasarkan konten, konstruk, dan bahasa yang akan di ujicobakan pada tahap one-to-one. Dalam hal ini soal yang telah dinyatakan valid oleh validator ditampilkan dalam Tabel 2.

\section{Tabel 2. Prototype II}

1 Pebri dan Yongky berada di titik yang sama disuatu lapangan, Pebri berjalan lurus kearah barat sedangkan Yongky berjalan lurus kearah selatan. Pada waktu yang bersamaan mereka berhenti, kemudian Pebri berjalan kearah Yongky melalui jarak terdekat. Bangun datar apakah yang terbentuk dari garis perjalanan mereka?

2 Faris mempunyai kawat sepanjang $98 \mathrm{~cm}$. Kawat tersebut seluruhnya akan ia gunakan untuk membuat segitiga sama kaki dengan panjang sisi yang sama adalah $29 \mathrm{~cm}$. Jika luas daerah yang dibatasi oleh kawat tersebut $420 \mathrm{~cm}^{2}$, tentukanlah tinggi segitiga tersebut!

3 Debi mempunyai tugas membuat kerajinan tangan yang terbuat dari tiga potong bambu yang berbeda panjangnya. Untuk merekatkan satu bambu dengan bambu yang lain digunakan tiga paku sehingga terbentuk suatu bangun datar. Agar bambu terpanjang dapat direkatkan dengan dua bambu yang lain, maka dua bambu yang paling pendek harus direkatkan secara tegak lurus. Bangun datar apakah yang terbentuk dari kerajinan tangan yang dibuat oleh Debi? Jelaskan!

4 Ade, Nia dan Astri gemar mengoleksi stik es krim, setelah terkumpul banyak stik es krim ini digunakan oleh mereka untuk membuat kerajinan kotak pensil yang berbentuk segitiga 
seperti gambar dibawah ini. Jika setiap stik es krim berukuran $5 \mathrm{~cm}$ dan akan dibuat segitiga sebanyak 20 tingkat maka berapakah panjang keseluruhan stik es krim tersebut?

5 Di desa Sinar Gunung akan dibangun sebuah gapura. Untuk memperindah gapura, bagian atas gapura akan dicat. Bagian atas gapura tersebut berbentuk segitiga sama kaki dengan alas berukuran $4 \mathrm{~m}$ dan jarak dari tanah sampai ke puncak segitiga $5 \mathrm{~m}$, sedangkan tinggi tiang gapura $4 \mathrm{~m}$. Di tengah-tengah segitiga tersebut terdapat sebuah segitiga kecil yang berbentuk segitiga siku-siku dengan panjang sisi siku-siku nya $100 \mathrm{~cm}$ dan $80 \mathrm{~cm}$. Setiap satu kaleng cat dapat mengecat seluas $1000 \mathrm{~cm}^{2}$ dan dibeli dengan harga Rp. 30.000. Berapa biaya yang diperlukan untuk mengecat bagian atas gapura tersebut?

6 Kapal "Maritim" berlayar ke arah utara sejauh $55 \mathrm{~km}$ dari pelabuhan A menuju pelabuhan $\mathrm{B}$, kemudian dilanjutkan ke arah timur menuju pelabuhan $\mathrm{C}$ sejauh $48 \mathrm{~km}$. Saat kembali ke pelabuhan A kapal tersebut tidak melalui pelabuhan B, melainkan melalui jarak terpendek menuju pelabuhan A. Sebuah kapal lain, yaitu kapal "Bahari” berangkat dari pelabuhan $\mathrm{D}$ ke arah selatan menuju pelabuhan $\mathrm{C}$ sejauh $53 \mathrm{~km}$, kemudian menuju pelabuhan A dengan lintasan yang sama dengan lintasan kapal "Maritim" saat kembali ke pelabuhan A. Selanjutnya kapal "Bahari" kembali ke pelabuhan D dan memilih lintasan terdekat. Jika kecepatan kedua kapal diasumsikan sama, kapal manakah yang akan berlayar lebih lama?

7 Pak Deni akan membuat sebuah taman bunga berbentuk segitiga dengan panjang ketiga sisinya $5 \mathrm{~m}, 12 \mathrm{~m}$ dan $13 \mathrm{~m}$. Tentukanlah biaya untuk pembuatan taman pak Deni jika

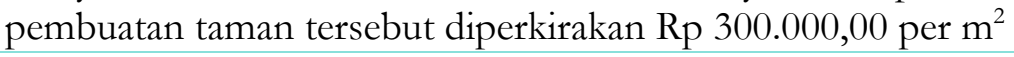

8 Terdapat sebuah segitiga LMS dengan panjang sisi LM $12 \mathrm{~cm}$ dan panjang sisi-sisi lainnya $\frac{3}{4}$ LM. Jika garis LP merupakan garis berat yang terdapat pada segitiga LMS, maka tentukanlah panjang MP!

9 Pak Beruan mempunyai kebun jagung seluas $84 \mathrm{~m}^{2}$ yang berbentuk segitiga dengan panjang sisi-sisinya $24, x$, dan $\sqrt{x^{2}+24^{2}}$ dalam satuan meter. Jika pak Beruan ingin memagari kebun jagung tersebut dengan pagar bambu. Berapa panjang pagar bambu yang mengelilingi kebun jagung tersebut?

10 Sebelum mengakhiri pembelajaran Ibu Maya memberikan kuis kepada seluruh siswa, siswa yang dapat menjawab dengan cepat dan benar diperbolehkan untuk pulang lebih awal dari siswa yang lain. Kuis yang diberikan oleh ibu Maya terdiri dari 1 pertanyaan yaitu “Terdapat sebuah segitiga PQR dengan panjang PQ $8 \mathrm{~cm}$, panjang QR $9 \mathrm{~cm}$, dan PR $6 \mathrm{~cm}$. Dari segitiga PQR tersebut adakah salah satu sudut yang ukurannya lebih dari $90^{\circ}$ ? Berikan alasan!"

Dari soal kuis tersebut dapatkah kamu membantu siswa menjawab pertanyaan dari ibu Maya?

\section{One-to-one}

Setelah prototype II telah selesai divalidasi oleh validator dan menghasilkan 10 soal yang valid. Selanjutnya, soal di ujicobakan kepada 3 orang siswa SMP kelas VII yang berkemampuan heterogen. Adapun komentar/saran siswa terhadap soal yang telah di ujicobakan dapat dilihat pada Tabel 3 berikut.

Tabel 3. Komentar siswa pada tahap uji coba one-to-one terhadap soal

\begin{tabular}{clll} 
Butir & \multicolumn{3}{c}{ Hasil wawancara terhadap soal } \\
\cline { 2 - 4 } soal & \multicolumn{1}{c}{ S1 } & \multicolumn{1}{c}{ S3 } \\
\hline 1 & Soal dapat dipahami & Soal dapat dipahami & Sudah dapat dipahami \\
2 & Soal dapat dipahami & Soal dapat dipahami & Soal cukup jelas \\
3 & Soal dapat dipahami & Soal cukup jelas & Soal dapat dipahami
\end{tabular}


Desain soal-soal kemampuan literasi...

\begin{tabular}{|c|c|c|c|}
\hline 4 & $\begin{array}{l}\text { Soal jelas dan dapat } \\
\text { dipahami }\end{array}$ & Soal dapat dipahami & Soal dapat dipahami \\
\hline 5. & Soal dapat dipahami & Soal dapat dipahami & $\begin{array}{l}\text { Soal dapat dipahami, tetapi } \\
\text { masih bingung cara } \\
\text { menghitungnya }\end{array}$ \\
\hline 6 & Soal jelas dapat dipahami & $\begin{array}{l}\text { Soal dapat dipahami, tetapi } \\
\text { masih bingung cara } \\
\text { menghitungnya }\end{array}$ & $\begin{array}{l}\text { Soal dapat dipahami, tetapi } \\
\text { cara penyelesaiannya tidak } \\
\text { tahu }\end{array}$ \\
\hline 7 & Soal dapat dipahami & Soal dapat dipahami & Soal dapat dipahami \\
\hline 8 & Soal dapat dipahami & Soal dapat dipahami & Soal dapat dipahami \\
\hline 9 & Soal dapat dipahami & Soal dapat dipahami & Soal dapat dipahami \\
\hline 10 & Soal dapat dipahami & $\begin{array}{l}\text { Soal dapat dipahami, tetapi } \\
\text { masih bingung cara } \\
\text { menyelesaikannya }\end{array}$ & $\begin{array}{l}\text { Soal dapat dipahami, tetapi } \\
\text { tidak tahu cara } \\
\text { penyelesaiannya }\end{array}$ \\
\hline
\end{tabular}

Keterangan:

S1: Siswa berkemampuan tinggi; S2: Siswa berkemampuan sedang; dan S3: Siswa berkemampuan rendah

Pada tabel 3, secara garis besar terlihat bahwa siswa telah memahami soal-soal yang di desain untuk kemampuan literasi matematis siswa sehingga soal-soal tersebut dapat digunakan, walaupun masih ada beberapa soal yang dianggap sulit bagi siswa. Dari hasil uji coba pada tahap one-to-one ini dapat disimpulkan bahwa butir-butir soal tersebut memiliki keterbacaan yang baik. Karena tidak ada soal yang direvisi setelah one-to-one maka soal final yang digunakan untuk diujikan pada tahap Small Group adalah soal prototype II.

Small Group

pada tahap ini prototype II diuji cobakan ke 30 siswa. Hasil dari uji pada tahap Small Group di tampilkan dalam Tabel 4.

Tabel 4. Kesimpulan hasil analisis butir soal

\begin{tabular}{lccc}
\hline No & $\boldsymbol{P}$ & $\boldsymbol{D} \boldsymbol{i}$ & Kesimpulan \\
1 & Sedang & Baik & Baik \\
2 & Sedang & Baik & Baik \\
3 & Mudah & Baik & Tidak Baik \\
4 & Sedang & Baik & Baik \\
5 & Sedang & Baik & Baik \\
6 & Sukar & Tidak Baik & Tidak Baik \\
7 & Sedang & Baik & Baik \\
8 & Sedang & Baik & Baik \\
9 & Sedang & Baik & Baik \\
10 & Sukar & Tidak Baik & Tidak Baik \\
\hline
\end{tabular}

Kesimpulan hasil analisis berdasarkan tingkat kesukaran $(P)$ dan indeks daya pembeda (di), soal yang baik adalah soal yang mempunyai tingkat kesukaran dan indeks daya pembeda soal dalam kategori baik. Dari hasil analisis butir soal diperoleh 7 butir soal dengan kategori baik yaitu soal nomor 1, 2, 4, 5, 7, 8 dan 9 .

Pengembangan soal ini telah melalui serangkaian proses pengembangan mulai dari tahap preliminary, self-evaluation, experts review, one-to-one dan small group sehingga menghasilkan sebuah produk. Produk yang dimaksud tersebut adalah soal kemampuan literasi matematis siswa SMP kelas VII pada materi segitiga yang valid dan praktis. 
Valid terlihat dari hasil validasi oleh ketiga validator, dimana validator menyatakan soal sudah baik berdasarkan konten, konstruk, dan bahasa. Valid secara konten, soal yang dikembangkan telah sesuai dengan indikator kemampuan literasi matematis siswa, soal sesuai dengan materi segitiga, soal sesuai dengan kriteria masalah, isi materi yang ditanyakan sudah sesuai dengan jenjang jenis sekolah, atau tingkat kelas. Valid secara konstruk, soal sudah menggunakan kata tanya/perintah yang menuntut jawaban terurai, ada petunjuk jelas tentang cara mengerjakan soal, soal memiliki pedoman penskoran dan gambar, grafik atau sejenisnya disajikan dengan jelas dan terbaca. Valid secara bahasa yaitu soal sesuai dengan EYD, soal tidak berbelit-belit dan mudah dipahami serta butir soal menggunakan bahasa yang baik dan benar. Selain itu, soal juga telah praktis, dilihat dari keterbacaan tiga orang siswa dimana hampir semua siswa dapat memahami soal dengan baik.

Setelah soal dinyatakan valid dan praktis, kemudian soal diuji cobakan kepada 30 siswa kelas VII SMPN 02 Kepahiang untuk menganalisis validasi butir soal. Hal ini dilakukan untuk memperoleh butir soal yang valid secara kuantitatif yaitu menentukan karakteristik butir soal dengan tingkat kesukaran dan indeks daya beda butir soal. Dari hasil analisis tersebut diperoleh soal yang dikategori baik ditinjau dari tingkat kesukaran dan indeks daya beda yaitu soal nomor $1,2,4,5,7,8$ dan 9. Sehingga dapat disimpulkan bahwa 7 butir soal kemampuan literasi matematis siswa SMP kelas VII pada materi segitiga yang dikembangkan dalam penelitian ini telah valid secara kualitatif dan kuantitatif.

Beberapa penelitian tentang pengembangan soal kemampuan literasi matematis antara lain : Penelitian yang dilakukan oleh (Putra dkk., 2016) menghasilkan, prototype perangkat soal yang dikembangkan dikategorikan valid dan praktis. Valid secara teoritik dapat dilihat dari hasil penilaian validator, dimana hampir semua validator mengatakan soal telah baik berdasarkan konten, konstruk dan bahasa, adapun valid secara kriteria dapat dilihat berdasarkan analisis butir soal dan analisis item butir soal, sedangkan praktis tergambar dari hasil uji coba one-to-one, dan small group dimana semua siswa dapat memahami perangkat soal dengan baik serta soal yang dikembangkan memiliki efek potensial terhadap kemampuan literasi matematis siswa.

Penelitian lain juga diteliti oleh (Asmara \& Sari, 2021) menghasilkan suatu produk yaitu 14 soal essai kemampuan literasi matematis level 3 siswa SMP kelas VII materi aritmetika sosial yang valid dan praktis. Kevalidan soal terlihat dari hasil pada tahap expert review atau hasil penilaian dari validator berdasarkan konten, konstruk, dan bahasa. Kepraktisan soal terlihat dari hasil pada tahap one-to-one atau komentar/saran siswa bahwa siswa dapat mengerti, memahami maksud dan tujuan dari soal, serta dapat terlihat dari analisis kuantitatif yaitu soal dari nomor 1 hingga 14 dikategorikan praktis dengan nilai rata-rata yang berada pada interval $3 \leq \mathrm{Mp}<4$.

Dari beberapa penelitian diatas, dapat disimpulkan bahwa pengembangan soal kemampuan literasi matematis untuk siswa SMP dikategorikan sangat valid dan praktis untuk digunakan sebagai acuan sumber pembelajaran bagi siswa.

\section{KESIMPULAN}

Penelitian ini menghasilkan suatu produk yaitu 10 soal esai kemampuan literasi matematis untuk siswa SMP materi segitiga yang valid dan praktis. Kevalidan soal terlihat dari hasil pada tahap expert review atau hasil penilaian dari validator berdasarkan konten, konstruk, dan bahasa. Kepraktisan soal terlihat dari hasil pada tahap one-to-one atau komentar/saran siswa bahwa siswa dapat mengerti, memahami maksud dan tujuan dari soal. Dari hasil analisis soal pada tahap small group berdasarkan tingkat kesukaran dan indeks daya pembeda diperoleh 7 butir soal dengan kategori baik.

\section{DAFTAR PUSTAKA}

Allen, M. J., \& Yen, W. M. (1979). Introduction to measurement theory. California: Cece Munshon.

Anwar, N. T. (2018). Peran kemampuan literasi matematis pada pembelajaran matematika abad-

21. Prosiding Seminar Nasional Matematika, 1, 364-370. 
Desain soal-soal kemampuan literasi...

Asmara, A., \& Risnanosanti, R. (2019). Literasi matematika siswa smp melalui model problem based learning. Jurnal MATH-UMB.EDU, 6(3). https://doi.org/10.36085/math-umb.edu.v6i3.498

Asmara, A., \& Sari, D. (2021). Pengembangan soal aritmetika sosial berbasis literasi matematis siswa SMP.Jurnal Cendekia: Jurnal Pendidikan Matematika, 5(3), 2950-2961. https://doi.org/10.31004/cendekia.v5i3.982

Masjaya, M., \& Wardono, W. (2018). Pentingnya kemampuan literasi matematika untuk menumbuhkan kemampuan koneksi matematika dalam meningkatkan SDM. PRISMA, Prosiding Seminar Nasional Matematika, 1, 568-574. Retrieved from https://journal.unnes.ac.id/sju/index.php/prisma/article/view/20196

Nahdi, D. S. (2019). Keterampilan matematika di abad 21. Jurnal Cakrawala Pendas, 5(2), 133-140. http://dx.doi.org/10.31949/jcp.v5i2.1386

OECD. (2019), PISA 2018 results (volume I): what students know and can do, PISA. Paris: OECD Publishing. https://doi.org/10.1787/5f07c754-en

Putra, Y. Y., Zulkardi, Z., \& Hartono, Y. (2016). Pengembangan soal matematika model PISA konten bilangan untuk mengetahui kemampuan literasi matematika siswa. Jurnal Elemen, 2(1), 14-26. https://doi.org/10.29408/jel.v2i1.175

Ramadianti, W., Syofiana, M., \& Mahyudi, M. (2018). Pengembangan soal matematika open-ended berkonteks bumi raflesia. SJME (Supremum Journal of Mathematics Education), 2(1), 8-16. https://doi.org/10.35706/sjme.v2i1.922

Sari, R. H. N. (2015). Literasi Matematika: Apa, Mengapa dan Bagaimana?. Seminar Nasional Matematika Dan Pendidikan Matematika UNY 2015, 713-720.

Sasongko, T. P. M., Dafik, D., \& Oktavianingtyas, E. (2016). Pengembangan paket soal model PISA konten space and shape untuk mengetahui level literasi matematika siswa SMP. Jurnal Edukasi, 3(1), 27-32. 10.19184/jukasi.v3i1.4317

Sumiati, A., \& Agustini, Y. (2020). Analisis kesulitan menyelesaikan soal segiempat dan segitiga siswa SMP kelas VIII di Cianjur. Jurnal Pendidikan Matematika, 4(1), 321-330.

Susanti, V. D., \& Maharani, S. (2016). IbM membangun "desa cermat" melalui bimbingan belajar dalam meningkatkan hasil belajar matematika siswa. Jurnal Terapan Abdimas, 1, 39. https://doi.org/10.25273/jta.v1i1.341

Wibowo, A. A., Ri'fat, M., \& Yani, A. (2019). Pengembangan Instrumen tes untuk mengukur kemampuan literasi matematis siswa SMP. AULADUNA: Jurnal Pendidikan Dasar Islam, 5(1), 1-12. https://doi.org/10.24252/auladuna.v5i1a1.2018

Zulkardi, Z. (2006). Formative evaluation: What, why, when, and how. Retrieved from http://www.oocities.org/zulkardi/books.html 